\title{
Analysis and Evaluation of the Urban Rainwater Harvesting System in Green Buildings
}

\author{
Li Hongmin ${ }^{1, *}$, and Yan $\mathrm{Lu}^{2}$ \\ ${ }^{1}$ School of Civil Engineering and Architecture, Wuhan Polytechnic University, Wuhan, China \\ ${ }^{2}$ Hubei Audit Office, Wuhan, China
}

\begin{abstract}
In the present study, urbanization provides residents with superior material and cultural living conditions, but also brings series of problems such as environmental pollution and water supply and drainage issues. Urban rainwater utilization is one of the method to solve urban water shortage and reduce waterlogging disaster.Taking an office building in Wuhan as an example, based on the analysis of rainfall characteristics in Wuhan, this thesis demonstrates a rainwater utilization system by rational use of the structural form of buildings, and analyzes and evaluates the function of the system with actual data. It is feasible and necessary to prove its comprehensive benefit according to the input and revenue. And the system is economic and reasonable for the project and the society as a whole. Based on the specific project, the author summarizes experiences and put forward effective suggestions.
\end{abstract}

\section{Preface}

With the development of urbanization in all countries of the world, the scale of cities is growing, and the number of cities is also increasing rapidly. On the one hand, urbanization provides residents with superior material and cultural living conditions, but also brings series of problems such as environmental pollution and water supply and drainage issues[1-3]. In the water supply and drainage system, especially the continuous expansion of the paved area of the impervious surface and the increase of the building density, the formation time of the surface runoff is shortened, the peak flow rate is continuously increased, the flow rate of the drainage system is greatly increased, the chance of flood disasters increases, and the damage is intensified[4]. In the past 30 years, more than 40 countries and regions such as the United States, Canada, Germany, and Japan have carried out research on rainfall flood. Among them, the use of rainwater in the United States and Japan started earlier and was more advanced[5]. Since the 1960s, Japan has built flood pools with various types of flood detention and accumulated rainwater, and used the accumulated rainwater as urban miscellaneous water such as spray pavement and grassland irrigation. Many states in the United States have studied roof storage and surface recharge systems formed by infiltration ponds, wells, grasslands, and permeable pavements[6].

Through research, exploration and practice in recent years, people have gradually realized the importance of rainwater utilization and the economic, social, ecological and environmental benefits that can be obtained[7].

Wuhan is a north subtropical monsoon (wet) climate with abundant rainfall, abundant heat, and distinct in four seasons. Wuhan has developed rapidly in the past ten years, which has made it difficult for municipal facilities to keep up with the pace of urban development. The annual rainy season has potential floods. How to effectively use this abundant rainwater resource in cities to eliminate hidden dangers and bring benefits is a very good subject. This paper analyzes the accumulation and utilization of urban rainwater in the specific case of an office building in Wuhan.

\section{Project Overview}

Under the background of global climate change, it is imperative to develop green building. And the construction project we mention subsequently is named as a green building.and the rainwater harvesting system of it is remarkably well.

The construction project is located in the east of Wuhan Donghu National Independent Innovation Demonstration Zone, north of Gaoxin Avenue and west of the Outer Ring Expressway. The topography and landform types in this project area are relatively simple, and the relative height difference is small. It belongs to the low mountain and low hill area, and is mainly based on the ridge and landform. Because the project is surrounded by urban artificial ecological environment, it is within the scope of human development activities. The project is a typical urban construction building.

The planned land area for the project is $87,739.43 \mathrm{~m}^{2}$, the building covers an area of $17010 \mathrm{~m}^{2}$, the outdoor ground area is $70857.43 \mathrm{~m}^{2}$, and the outdoor permeable floor area is $44440.31 \mathrm{~m}^{2}$, of which the green area is $33,717 \mathrm{~m}^{2}$. The roads are made of permeable concrete roads and the parking spaces are made of grass bricks.

\footnotetext{
* Corresponding author: 313833354@qq.com
} 
For the permeable floor, the total area of roads and parking spaces is $10623.31 \mathrm{~m}^{2}$.

The main building collects rainwater on the roof. A $100 \mathrm{~m}^{3}$ rainwater reservoir is installed on the 16th floor. The rainwater is treated by $10 \mathrm{~m}^{3} / \mathrm{h}$ integrated rainwater treatment equipment and pumped into the 18th floor $238 \mathrm{~m}^{3}$ roof pool for 11 th floor and above. The rainwater overflowing from the pool enters the $300 \mathrm{~m}^{3}$ underground rainwater reservoir, and is pumped into the underground pool of $150 \mathrm{~m}^{3}$ after being treated by $10 \mathrm{~m}^{3} / \mathrm{h}$ integrated rainwater treatment equipment. The variable frequency pressure pump is used to supply $10^{\text {th }}$ floor and the below floors. The annual rainwater consumption is $6296 \mathrm{~m}^{3}$. The site collects road surface and paved rainwater. A $390 \mathrm{~m}^{3}$ rainwater reservoir is installed in the site. The rainwater is treated by $10 \mathrm{~m}^{3} / \mathrm{h}$ integrated rainwater treatment equipment and pumped into a $50 \mathrm{~m}^{3}$ clear water pool for green irrigation and road pouring. The annual rainwater usage is $8840.67 \mathrm{~m}^{3}$. After the rainwater is treated by the water treatment process, the water quality complies with the current national standard. That is to say, the water can be reused.

\section{3 design and calculation of rainwater harvesting system}

\subsection{Project characteristics and system design}

The shape of the main building looks like morning glory. The roof area is large, and that determines the high utilization rate of the rainwater harvesting system.

According to the calculation, the rainwater drainage system is arranged as mentioned in section 2, and all the parts fit together properly.

\subsection{Part of the data used in the design}

The comparison of rainwater harvesting amount and actual rainwater usage is shown in the following table1-3. As can be seen from the table below, the building can collect rainwater of $8,967 \mathrm{~m}^{3}$ for the whole year and actual $6,674 \mathrm{~m}^{3}$ rainwater which are treated by the equipment are reused.

Table 1. Comparison table of rainwater collection and actual rainwater usage in the main building(1-6 month)

\begin{tabular}{|c|c|c|c|c|c|c|}
\hline month & 1 & 2 & 3 & 4 & 5 & 6 \\
\hline $\begin{array}{c}\text { Precipitation( } \\
\text { mm) }\end{array}$ & 78 & 68 & 83 & 133 & 168 & 183 \\
\hline $\begin{array}{c}\text { Rainwater } \\
\text { can be } \\
\left.\text { used(m }{ }^{3}\right)\end{array}$ & 545 & 475 & 580 & 929 & 1173 & 1278 \\
\hline $\begin{array}{c}\text { Recycled } \\
\text { rainwater } \\
\left(\mathrm{m}^{3}\right)\end{array}$ & 490 & 427 & 522 & 836 & 1056 & 1150 \\
\hline $\left.\begin{array}{c}\text { Recycled } \\
\text { water } \\
\text { used(m }\end{array}\right)$ & 624 & 624 & 624 & 624 & 624 \\
\hline $\begin{array}{c}\text { Excess } \\
\left.\text { rainfall(m } \mathrm{m}^{3}\right)\end{array}$ & -133 & -196 & -102 & +212 & +432 & +527 \\
\hline rainfall & & & & \\
\hline
\end{tabular}

\begin{tabular}{|c|c|c|c|c|c|c|}
\hline lacked $\left(\mathrm{m}^{3}\right)$ & & & & & & \\
\hline $\begin{array}{c}\text { summation of } \\
\text { rain used }\left(\mathrm{m}^{3}\right)\end{array}$ & 490 & 427 & 522 & 624 & 624 & 624 \\
\hline
\end{tabular}

Table 2. Comparison table of rainwater collection and actual rainwater usage in the main building(7-12 month)

\begin{tabular}{|c|c|c|c|c|c|c|}
\hline month & 7 & 8 & 9 & 10 & 11 & 12 \\
\hline $\begin{array}{l}\text { Precipitation( } \\
\mathrm{mm} \text { ) }\end{array}$ & 202 & 108 & 57 & 83 & 82 & 39 \\
\hline $\begin{array}{l}\text { Rainwater } \\
\text { can be } \\
\text { used }\left(\mathrm{m}^{3}\right)\end{array}$ & 1411 & 254 & 398 & 580 & 573 & 272 \\
\hline $\begin{array}{l}\text { Recycled } \\
\text { rainwater } \\
\left(\mathrm{m}^{3}\right)\end{array}$ & 1270 & 679 & 358 & 522 & 515 & 245 \\
\hline $\begin{array}{c}\text { Recycled } \\
\text { water } \\
\text { used }\left(\mathrm{m}^{3}\right) \\
\end{array}$ & 624 & 624 & 624 & 624 & 624 & 624 \\
\hline $\begin{array}{l}\text { Excess } \\
\text { rainfall }\left(\mathrm{m}^{3}\right)\end{array}$ & +646 & +55 & & & & \\
\hline $\begin{array}{c}\text { rainfall } \\
\text { lacked }\left(\mathrm{m}^{3}\right)\end{array}$ & & & -265 & -102 & -108 & -379 \\
\hline $\begin{array}{l}\text { summation of } \\
\text { rain used }\left(\mathrm{m}^{3}\right)\end{array}$ & 624 & 624 & 624 & 624 & 624 & 245 \\
\hline
\end{tabular}

\subsection{Water supply and drainage system deployment}

The annual water consumption of the main building is $17,545 \mathrm{~m}^{3}$, the annual rainwater consumption is $6,296 \mathrm{~m}^{3}$ and the municipal water consumption is $6,810 \mathrm{~m}^{3}$. The total annual water consumption of the site greening and road pouring is $1640.86 \mathrm{~m}^{3}$, and the rainwater treated is fully used. After the rainwater is treated by the water treatment process, the water quality standard complies with the current national standard, that is "the Urban Wastewater Recycling Urban Miscellaneous Water Quality" (GB/T 18920-2002).

According to the requirements of the code, the outdoor fire water supply loop pipe is formed in the project area by the two-way municipal water supply pipe. The diameter of the loop pipe is DN250, and the outdoor fire water is supplied by the loop pipe. A $396 \mathrm{~m}^{3}$ fire pool is installed in the pumping room on the ground floor, and the indoor fire water is provided by the pool. Indoor fecal sewage and domestic waste water are diverted, and the outdoor drainage system is rainwater and sewage diversion. The use of high-efficiency highquality pipes, valves, connections to prevent leakage of the pipe network, all water appliances use water-saving appliances.

\subsection{Set up a reasonable water supply and drainage system}

The maximum daily water consumption of the project is $775 \mathrm{~m}^{3}$, the maximum hourly water consumption is $181 \mathrm{~m}^{3}$, and the municipal water pressure is $0.16 \mathrm{MPa}$. The first floor of the main building is directly supplied by the municipality; the second floor and the above of 
the main building is supplied by variable frequency pressurized pumps.

In order to avoid leakage of pipe network effectively, the main building equips qualified products for pipe materials, pipe fittings and valves. In addition, the water supply system (including rainwater collection and reclaimed water) is installed with classified longdistance meters to record the data of water consumption. And furthermore, by rationalizing water use analysis, the system could help the building manager identify water leakage points and realize the water saving potential.

The roads and parking spaces in the site are all permeable floors. The rainwater can be infiltrated into the ground.

\section{4 economic evaluation}

\subsection{User Cost Analysis}

\subsubsection{Investment in infrastructure equipment}

The reservoir is made of reinforced concrete, which is designed by professional manufacturers. The construction, infrastructure and equipment investment totals 668,000 yuan.

\subsubsection{Operating costs}

There are many factors influencing the operating cost of the rainwater system, which are related to the gap between the operation scale, the design scale and the actual processing scale, equipment investment, maintenance costs, electricity costs, and labor costs.

The project refers to the relevant project experience, the rainwater processing cost of $1 \mathrm{~m}^{3}$ water is 1.53 yuan, the daily input cost is 63.45 yuan, and the annual input cost of rainwater system is 23159.10 yuan.

According to the depreciation period of equipment in the "Accounting Standards for Business Enterprises - Fixed Assets", the depreciation period of the mechanical equipment of this system is converted to the highest value of 10 years, the residual value rate is $5 \%$, the annual depreciation amount is 63,460 yuan. That is the basis of the assessment.

\subsection{Input-output analysis}

Rainwater facilities are different from drainage facilities and other municipal and environmental facilities. The project investment itself not only has direct economic benefits, but also indirect economic benefits and relatively quantitative environmental benefits. So, when it evaluates the input and output, the following four aspects should be considered.

\subsubsection{Saving the marginal cost of urban water diversion and clean water}

According to the regulations of the Wuhan Municipal Price Bureau on the price of water, the final water price for general industrial and commercial enterprises is 3.15 yuan $/ \mathrm{m}^{3}$, and the design and utilization of rainwater for the whole year is $35,040 \mathrm{~m}^{3}$. The annual water saving system of the rainwater recovery system is $(3.15-1.53) \times$ $15136.67=24521.4$ yuan .

\subsubsection{Social losses reduced by eliminating pollution}

According to the analysis, the environmental resource loss is reduced by 3 yuan for every 1 yuan invested in environmental project. Since the rainwater facility does not include sludge treatment, the environmental resource loss that can be reduced should be less than 3 yuan. Let the input-output ratio be $1: 1.5$, that is, the input of rainwater per $1 \mathrm{~m}^{3}$ is 1.53 yuan, and the pollution loss can be reduced by $1.53 \times 1.5=2.30$ yuan. After using the rainwater recovery system, the main building gets benefit from it. There are $15136.67 \mathrm{~m}^{3}$ of water provided every year, which can reduce pollution loss. That is $34,814.34$ yuan.

\subsubsection{Saving construction and operation costs of urban drainage facilities}

The construction cost of urban drainage facilities is based on an estimated investment of 1 million $\mathrm{m}^{3}$ and a required investment of 1.8 billion yuan.

The daily treatment of $1 \mathrm{~m}^{3}$ sewage meter is 1,800 yuan. If the design period is 30 years, the sewage of $1 \mathrm{~m}^{3}$ is 0.16 yuan; the operating cost of the activated sludge method of urban sewage treatment facilities is 0.25 yuan $/ \mathrm{m}^{3}$, the total of the two is 0.41 yuan $/ \mathrm{m}^{3}$; the operating cost of the pipe network is roughly one-third of the treatment facility, plus the cost of the pipe network is roughly 0.49 yuan $/ \mathrm{m}^{3}$.

In summary, the construction and operation costs of the drainage facilities are $15136.67 \times 0.49=7416.97$ yuan based on the calculation above.

\subsubsection{National financial revenue increased by water savings}

At present, due to the lack of water, the country's fiscal revenue is lost. It is understood that the current average annual water shortage in more than 600 cities nationwide is about 10 million $\mathrm{m}^{3}$, resulting in a reduction of the national fiscal revenue by about 20 billion yuan per year, equivalent to a loss of 0.2 yuan per $1 \mathrm{~m}^{3}$ of water shortage.

After using the rainwater recovery system, it can provide $15136.67 \mathrm{~m}^{3}$ of water per year, and the stop-loss income is 3027.33 yuan per year.

\subsection{Comprehensive benefits}

The rainwater recovery system has a warranty period of 25 years. The statistics of various costs and comprehensive income statistics are showed in table 4 as follows: 
Table 3. Cost and comprehensive income statistics

\begin{tabular}{|c|c|c|c|}
\hline \multicolumn{2}{|c|}{ Cost } & \multicolumn{2}{|c|}{ revenue } \\
\hline $\begin{array}{c}\text { infrastructure } \\
\text { and } \\
\text { equipment }\end{array}$ & $¥ 668,000$ & $\begin{array}{l}\text { Water saving } \\
\text { benefits }\end{array}$ & $\begin{array}{l}24521 \times \\
25\end{array}$ \\
\hline $\begin{array}{l}\text { operation } \\
\text { maintenance }\end{array}$ & $23159 \times 25$ & $\begin{array}{c}\text { Financial input } \\
\text { saved }\end{array}$ & $\begin{array}{c}3027 \times 2 \\
5\end{array}$ \\
\hline & & pollution reduced & $\begin{array}{c}34814 \times \\
25\end{array}$ \\
\hline & & $\begin{array}{c}\text { drainage } \\
\text { construction and } \\
\text { operation saved }\end{array}$ & $\begin{array}{c}7417 \times 2 \\
5\end{array}$ \\
\hline \multicolumn{2}{|c|}{ Summation: $¥ 1,247,000$} & \multicolumn{2}{|c|}{ Summation: $¥ 1,744,500$} \\
\hline
\end{tabular}

\section{Conclusion}

To sum up, under the reasonable treatment scale and normal management, the project has guaranteed water quantity, short transportation distance, and can reduce the load of urban water supply and drainage facilities and reduce environmental pollution. The rainwater harvesting system has positive benefits in the whole life cycle, which is economic and reasonable for the project and the society as a whole.

Based on the specific project, the experience is as follows:

(1) Once the designer choose the roof rainwater system, he should take it into account at the preliminary design stage. Otherwise, it will bring great trouble in the subsequent work.

(2) In the design of roof rainwater system, it is necessary to fully understand the spatial characteristics and structural practices inside the building. The designer should closely coordinate with all parties involved in the whole process, formulate solutions to solve problems, coordinate the system design with the building itself, and achieve a harmonious and unified design effect.

China is a country with diverse topography and uneven distribution of water resources. At the same time, we should combine landscape science, aesthetics, design and other comprehensive disciplines to discuss the rainwater utilization under the new situation and the functional play mechanism of modern and contemporary urban landscape design.

\section{References}

1. M. Zaizen, T. Urakawa, Y. Matsumoto, et al. The collection of rainwater from dome stadiums in Japan. Urban Water, 1(4):355-359 (2000)

2. W. Liu, W. Chen, C. Peng. Assessing the Effectiveness of Green Infrastructures on Urban Flooding Reduction: A Community Scale Study. Ecological Modelling. 291(1):6-14 (2014)
3. H. Zhou, J. Gao and C. Gao. Analysis of Current Situation and Problems of Urban Waterlogging Control in China. Journal of Catastrophology, 33(3):147-151(2018)

4. W. Zheng. Drainage design of sponge industrial site. Coal Engineering. 50(6): 30-36(2018)

5. L. Ge, G. Xie and S. Li. The Analysis of Water Footprint of Production and Water Stress in China. Journal of Resources and Ecology. 7(5):334340(2017)

6. H. Wang. Study of the non steady state condition hydraulic test in the siphonic roof drainage system. Water and wastewater Engineering. 45(3):100105(2019)

7. W. Zhang, X. Y. Zhang, J. L. Fan, et al. Runoff pollution characterization and first flush effect of urban roof catchment. Desalination and Water Treatment. 119:262-266(2018) 